\title{
Characterization and effect of the use of safflower methyl ester and diesel blends in the compression ignition engine
}

\author{
Balaji Venkatesan ${ }^{1, *}$, Kaliappan Seeniappan ${ }^{2}$, Ezhumalai Shanmugam ${ }^{1}$, Socrates Subramanian ${ }^{2}$, \\ and Jayaseelan Veerasundaram ${ }^{3, *}$

\footnotetext{
${ }^{1}$ Department of Mechanical Engineering, Loyola Institute of Technology, Chennai 600123, Tamil Nadu, India

${ }^{3}$ Department of Mechanical Engineering, Prathyusha Engineering College, Poonamalle Road, Chennai 602025, India
} \\ ${ }^{2}$ Department of Mechanical Engineering, Velammal Institute of Technology, Chennai 600066, Tamil Nadu, India
}

Received: 12 December 2020 / Accepted: 8 March 2021

\begin{abstract}
Energy is vital to the profitable growth of every nation and to stimulate new research. Only natural resources can meet the growing energy demand in recent years, biodiesel has become very interested in the energy as well as environmental advantages that it can be combined with mineral diesel fuel in any quantity. The research focuses on the study of the replacement of diesel with a safflower methyl ester. The engine tests shall be performed using the safflower methyl ester as fuel in the DI diesel engine. The combustion, emission and performance characteristics were studied using alternative fuels and mixtures. Safflower Methyl Ester $80 \%$ (SAME80) and SAME100 have high heat release rates. Nitrogen oxides were higher by about 50\%, carbon monoxide decreased by $10 \%$, unburnt hydrocarbon was slightly higher and the thermal efficiency was higher for the SAME than for diesel fuel.
\end{abstract}

\section{Introduction}

The use of powerful diesel engines needs help in the future, as the fuel consumed is lower and potent greenhouse gases such as carbon dioxide are substantially reduced (Antolin et al., 2002). The growing use of diesel, huge trade flows and environmental issues have led to developing nations like India finding an environmentally friendly alternative to diesel fuel. The country's dependence on oil-rich countries is growing due to a highly accountable energy shortage (Demirbas, 2007). It raises the country's import bill. The rise in the bill is a major concern for the lack of global trade tools and the energy supply shortages are highly responsible. Petroleum products are commonly used by transport, agriculture and industries. In the modernised agricultural sector, it plays a crucial role (Dorado et al., 2003). The eradication of Internal Combustion (IC) engines cannot be achieved. To use current engines in an effective way, alternative fuel is the solution and it must be obtainable (Kinoshita et al., 2004). There have been some considerations concerning the selection of suitable alternatives to petroleum-based fuels. Several steps to encourage the conservation of petroleum resources have been taken (Murugan et al., 2008). These include improved refining energy production and increased transport fuel efficiency.

\footnotetext{
* Corresponding author: balajee2000@gmail.com,

jaiseelanv@gmail.com
}

Furthermore, the exhaust of the engine accumulates in the air pollutants. To minimise the impact on the environment of exhaust gas emissions and the depletion of fossil fuel reserves, alternative fuels are needed. Alternatives such as fuel injector, transportation of fuel, storage and transmission should be compatible with the current engines (Schlick et al., 1988).

Biofuels are typically more efficient than fossil-fuel production, but their use can lead to reducing transportation pollution (Lesnik et al., 2020). In developing countries, energy demand is projected to increase by $90 \%$ and about a third of this energy will come from renewable energies, including biofuels. The only alternative to fossil fuels available in the world is biofuel from extracted biomass (Vignesh et al., 2021). Safflower methyl ester oils, on the other hand, have been much favoured worldwide as edible raw material for biodiesel processing. The Compression Ignition (CI), as alternative fuel without motor modification due to high viscosity and density, is not fed with clean biodiesel up to 100\% (Soares and Rocha, 2018). However, it has been shown that pure biodiesel can be used without significant engine changes in diesel engines (Ozsezen and Canakci, 2011). Oil is a material that is largely suitable for the generation of biomass fuel, particularly in oil-importing countries all over the world, such as Turkey, as an alternative source of renewable energy.

In other words, the biodiesel fuel produced from safflower oil, which is not consumed by people in this 
country like food, can be beneficial to decline the dependency on fossil fuel. Experimented soya biodiesel in the heavy-duty engine and noticed a $25 \%$ decrease in $\mathrm{CO}$ emission, a $77 \%$ decrease in particulate matter and a $10 \%$ rise in NOx emission (Sharp et al., 2005). Research on the advanced CI engine fuelled with soybean biodiesel (B20) and concluded that decreased emission was the outcome of $\mathrm{CO}$ and particulate emission. The researchers finally stated that by varying the engine attributes, namely, exhaust gas recirculation levels and injection valve timing, the performance of the engine can be enhanced (Sirman et al., 2000). SAfflower Methyl Ester (SAME) has been considered a replacement fuel in a diesel engine under different operating conditions, but few attempts are being made to consider it to be a fuel in a CI engine (Karabas, 2014). It has been stated that safflower oil can be converted into SAME and used as a conventional diesel fuel based on the literature review (Yesilyurt et al., 2020). The work aims to study the combustion, emission and performance characteristics of the SAME and are compared with diesel.

\section{Fuel preparation}

A sample was prepared and the oil was bought for the experiment, hence the safflower is not accessible on a mass market. The viscosity of SAME in a diesel engine must be minimised. This is possible with transesterification, combining or pyrolysis from SAME with diesel (Yesilyurt et al., 2020). For the SAME mixing preparation, more time and work is required in different methods. Although the properties of high SAME are comparable to diesel, there may also be long-term problems with engine durability. Glycerin in the SAME system can cause problems with the engine fuel injection system in its non-modified form (Tutak et al., 2016). The structure will be adjusted and compliant with the engine fuel injection system by decreasing the viscosity of safflower oil using the transesterification process. This process is used to transform bio-oils with fats and large ramified triglyceride molecules into smaller molecules with straight chains close to diesel fuel molecules. A test to validate the consistency of biodiesel prepared in compliance with ASTM D 6751-07b is carried out before the characterization of SAME (Dwivedi and Sharma, 2014).

\section{Experimental work}

Figure 1 demonstrates the schematic view of the experimental setup. Table 1 displays the engine specifications. Tests are performed on SAME and SAME blends in stationary diesel engines. The load is applied with the power dynamometer on the generator. The torque is precisely measured using a loading cell-type pressure gauge to achieve output power.

\section{Results and discussion}

The findings are analysed and compared with diesel in the test on a stationary CI engine with the SAME and SAME

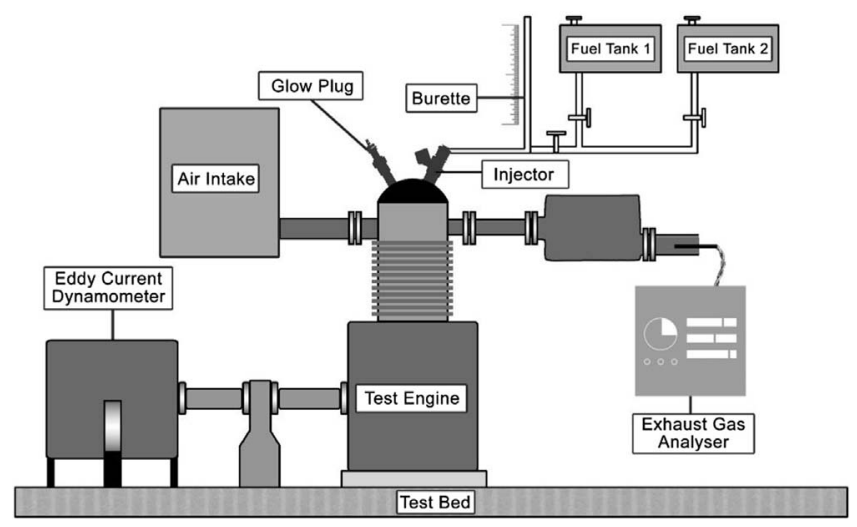

Fig. 1. Schematic view of the experimental setup.

Table 1. Engine specifications.

\begin{tabular}{lc}
\hline Engine & Kirloskar \\
\hline Type & TAF 1 \\
Injection-cooling & Direct injection, air-cooled \\
Bore $\times$ Stroke & $87.5 \times 110 \mathrm{~mm}$ \\
Compression ratio & $17.5: 1$ \\
CC & $0.661 \mathrm{~L}$ \\
Indicated power & $4.4 \mathrm{~kW}$ \\
Speed & $1500 \mathrm{rpm}$ \\
Injection angle & $23 \mathrm{CAD} \mathrm{bTDC}$ \\
\hline
\end{tabular}

blend. The properties of SAME, SAME blend and diesel are shown in Table 2.

\subsection{Combustion analysis}

\subsubsection{Combustion chamber pressure}

Figure 2 shows the combustion chamber pressure for the SAME, SAME blend and diesel in each crank angle at rated load. During the initial stage of combustion, the mixture of SAME and SAME will have a higher pressure compared to diesel (start of combustion at 4 CAD bTDC). The higher pressure of the SAME cylinder and its mixture during this time is due to its short ignition delay. This leads to an earlier start of combustion and also helps to increase the gaseous pressure by pushing the piston to the TDC. In the case of the SAME blends and SAME, the pressure of the cylinder is closer to TDC compared to diesel. Their lower heat release rate is mainly due to their lower heat emissions. SAME and its mixture show a slightly higher cylinder pressure (Hoekman et al., 2012). The density of diesel is less than the same. During the expansion stroke, the higher-end molecules in these fatty acids burn and create a slightly higher cylinder pressure.

\subsubsection{Ignition delay}

In Figure 3, the variations in Brake Power (BP) with ignition delay at various loads can be seen. Fuel ignition is a 
Table 2. Properties for SAME, SAME blend and diesel.

\begin{tabular}{lccccc}
\hline Fuel property & $\begin{array}{c}\text { Testing } \\
\text { method }\end{array}$ & Diesel & SAME & $\begin{array}{c}\text { SAME } \\
\text { blend }\end{array}$ & $\begin{array}{c}\text { Standard value as } \\
\text { per ASTM D 6751-07b }\end{array}$ \\
\hline Viscosity at $40{ }^{\circ} \mathrm{C}\left(\mathrm{mm}^{2} / \mathrm{s}\right)$ & Redwood viscometer & 3.3 & 4.1 & 3.62 & $1.9-6.0$ \\
Flashpoint $\left({ }^{\circ} \mathrm{C}\right)$ & ASTM D 92 & 70 & 169 & 80 & 130 min \\
Calorific value $(\mathrm{kJ} / \mathrm{kg})$ & ASTM D 240-02 & 43000 & 39436 & 42455 & $\sim 38912.7$ \\
Distillation temperature T90 $\left({ }^{\circ} \mathrm{C}\right)$ & ASTM D86 & 335 & 345 & 337 & 360 max \\
Specific gravity & - & 0.850 & 0.889 & 0.845 & 0.88 \\
Acid number $(\mathrm{mg} \mathrm{KOH} / \mathrm{gm})$ & - & - & 0.48 & - & 0.50 max \\
Calculated cetane index & ASTM D 4737 & 48.9 & 53.3 & 52.14 & 47 min \\
\hline
\end{tabular}

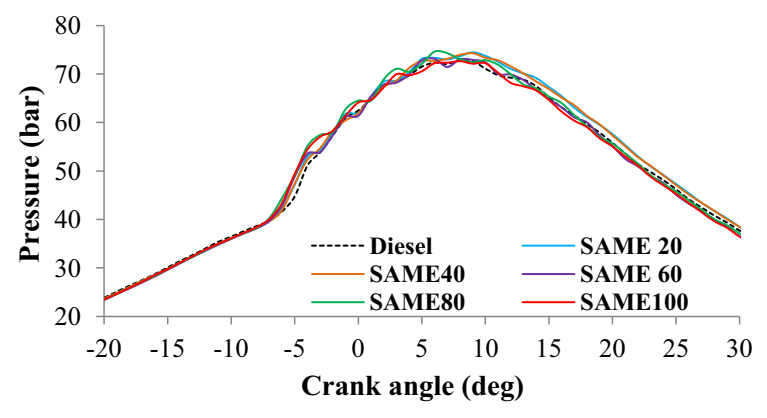

Fig. 2. Variation of combustion chamber pressure.

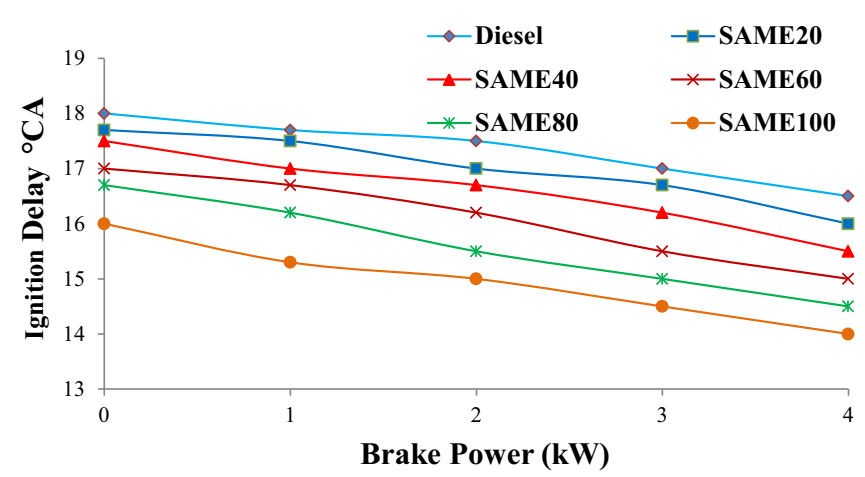

Fig. 3. Difference in ignition delay.

major factor that has an inverse effect on the amount of cetane. NOx formation takes place during the initiation of combustion and at the peak cylinder pressure. The NOx rate is influenced by an early burning mixer compressed at high temperatures. It is expressed as the time between the start of the injection and the combustion. As soon as combustion begins, the pressure increases dramatically (Capecchi et al., 2017). This raises the temperature of the braking system and reduces the delay time. The chemical reaction and polymerization of the SAME and SAME blends combine at high temperatures to ensure that the higher fatty acids of the SAME and SAME blends become lighter compounds.

\subsubsection{Flue gas temperature}

The variations in $\mathrm{BP}$ with flue gas temperatures for various loads are shown in Figure 4. For both fuels, the temperature of the flue gas increases with BP due to a higher amount of heat applied. The SAME and SAME blend temperatures are $17 \%$ higher and $9 \%$ higher than the diesel. The temperature of the SAME exhaust gas is $7^{\circ}$ higher than the SAME blends. As a result of $10 \%$ more biodiesel than diesel, fuel injection is started earlier by the pressure inside the fuel injector. As opposed to diesel, the viscosity of the SAME and SAME blend is $24 \%$ and $10 \%$ respectively, which raises the injection pressure. Because of this advantage, the needle-shaped plunger opens faster, combustion is advanced, and the temperature of the cylinder is increased compared to diesel (Carlos et al., 2014).

\subsubsection{Peak pressure}

Different researchers observe different patterns in varying peak pressures in methyl esters and their mixtures on diesel engines from the literature review. The peak pressures in a diesel engine are influenced by the early stage of combustion. Because of the long ignition delay in the precombustion stage more heat is released, the peak pressure increases. The highest pressure decrease is observed, with the increasing percentage of methyl ester. Figure 5 indicates variations in maximum pressures at varying loads for diesel, SAME and SAME blends.

More fuel is consumed at higher loads, resulting in greater peak pressures at higher loads to release more energy. Each load has a lower maximum pressure compared to diesel in the SAME and its blend. This is because their ignition delay at different loads is shorter than diesel. The flue gas produces more heat due to the high latent heat, which reduces maximum pressure and temperature (Kowalewicz and Wojtyniak, 2005).

\subsubsection{Rate of heat release}

Figure 6 shows the SAME and SAME blends compared to diesel which describe the rate of heat release at different angles of the crank. In the thermal release curve, the thermal energy availability potential is shown. Because the heat produced by SAME and SAME blends is low compared to diesel. In comparison with diesel, the difference in the heat 


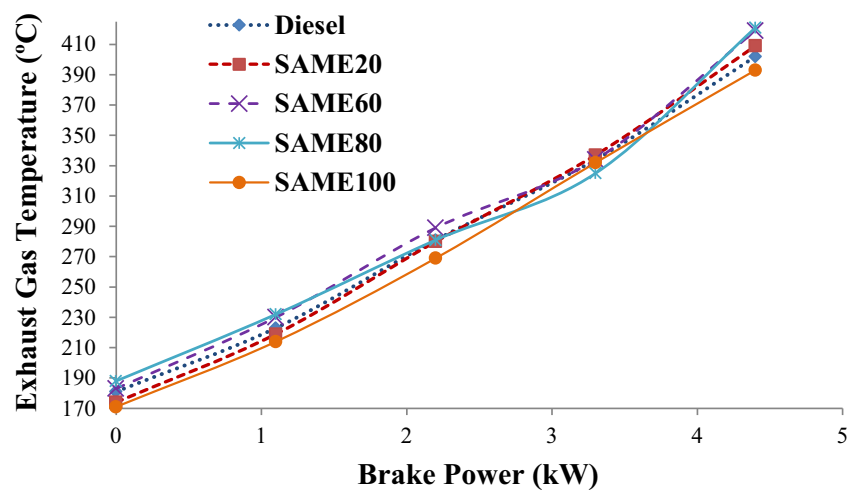

Fig. 4. Difference in flue gas temperature.

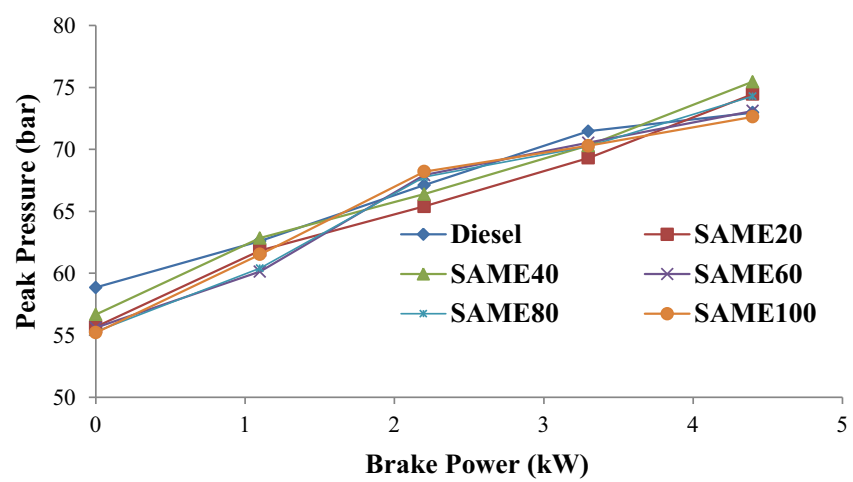

Fig. 5. Variable of peak pressure.

release rate is more significant than in the combustion chamber for the SAME80, SAME100. Since the temperature is inadequate in the combustion chamber during the early combustion stage. The heat release rate for SAME80 and SAME100 is high compared to diesel, as a result of rapid burns following TDC (Broatch et al., 2014).

The overall heat release rate of the SAME and SAME blends is $42 \%$ and $24 \%$, respectively compared to diesel, and its angle is increased by $2^{\circ}$ due to its shorter period. It is noted that the heat produced for the SAME and SAME blends is higher than diesel in the proximity of TDC. The average fatty acid density of safflower oil was $65 \%$ higher than that present in diesel hydrocarbons.

\subsubsection{Combustion duration}

The amount of energy that is emitted by burning fuel is defined by the angle of release of the heat. The angle of thermal release is the angle of the crank from the start of combustion to the required produced heat (Kaulani et al., 2019). Figure 7 shows the mean crank angle of time that $10 \%, 50 \%$ and $90 \%$ of the heat energy from the start is emitted by diesel, SAME and SAME blends at BP.

For larger BP, the volume of fuel is higher. The crank interval increases with BP to release $90 \%$ of the heat energy. For SAME and SAME blends, the combustion starts more early than diesel, so that it takes less crank

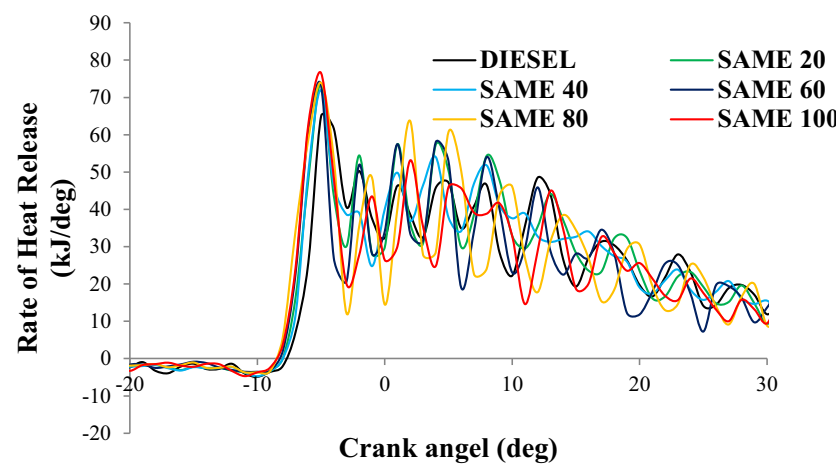

Fig. 6. Rate of heat release.

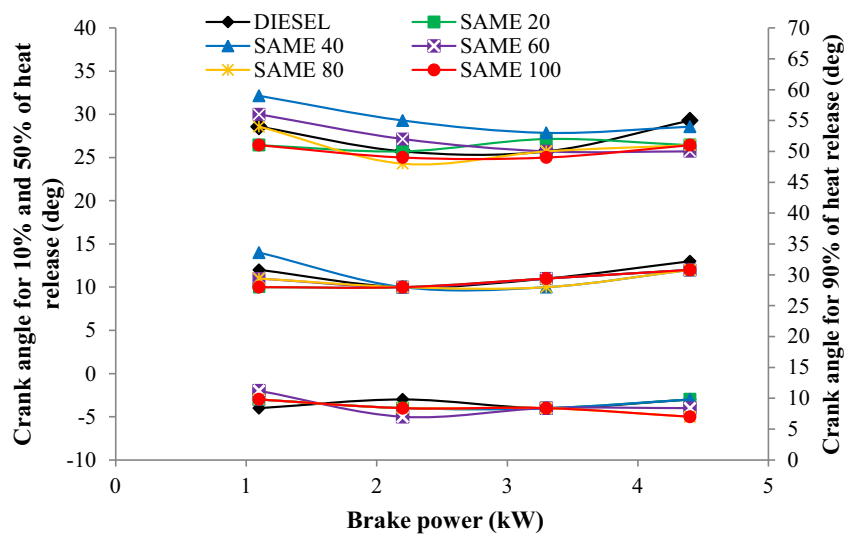

Fig. 7. Crank angle variations for $10 \%, 50 \%$ and $90 \%$ of heat release.

angle to produce $90 \%$ heat. For the SAME and SAME blend, the necessary crank angle is 3.8 and $3 \%$ earlier than diesel. The disparity in the crank angle of $90 \%$ for the SAME and SAME blends is shown to be less than that of diesel at different loads. Figure 8 displays the variation of combustion duration with BP.

\subsection{Emission analysis}

\subsubsection{NOx emission}

The NOx emissions vectors with brake power are revealed in Figure 9. NOx emissions are constantly rising with BP. It is noted, a significant amount of fuel and continuous air supply is pumped to have the same brake power. Owing to the increase in the richness of the mixture, NOx increases with BP. Also, the SAME and SAME blend's NOx emission are slightly higher than the diesel emissions by about $17 \%$ and $8 \%$ respectively. The rise in $\mathrm{BP}$ also increases the strength of the mixture and raises the oxygen required in the SAME and SAME blends. The combustion temperature raises the emission of NOx. SAME and SAME blends provide extra oxygen since this fuel is oxygen-based, which increases the use of free oxygen to work on nitrogen in the form of NOx at higher combustion temperatures. 


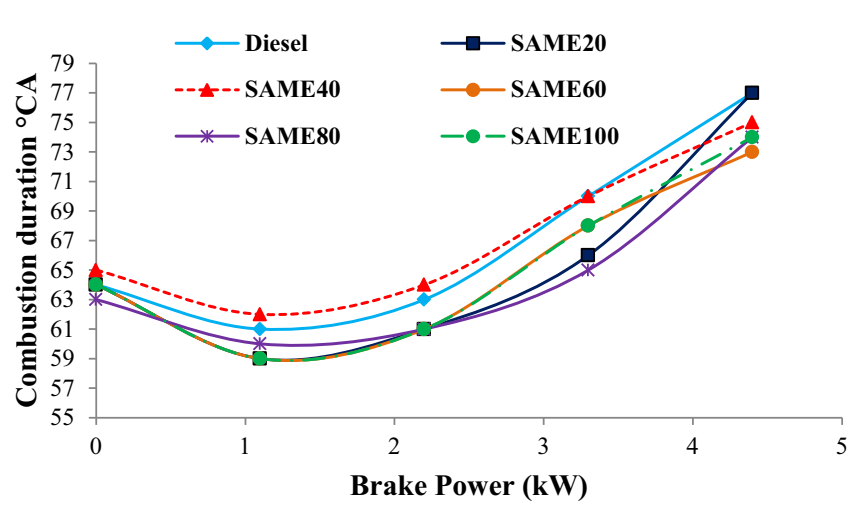

Fig. 8. Variation of combustion duration.

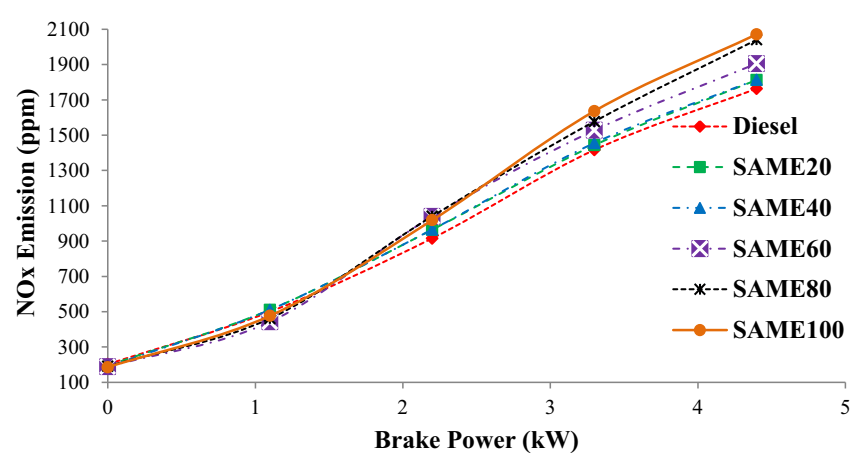

Fig. 9. Variation of NOx emission.

\subsubsection{Smoke opacity}

Figure 10 shows the SAME and SAME blends compared to diesel which describe the smoke opacity at different brake power. The smoke opacity of SAME and SAME blends is less than diesel. The viscosity of diesel is less than that of the SAME and SAME blends. The atomization of fuel and spray properties of the SAME and SAME combination can be affected. However, the mixture is lean in oxygen present in SAME and SAME blends and hence the smoke opacity of both the SAME and SAME blends is reduced.

The smoke opacity of SAME and SAME blends is approximately $44 \%$ and $40 \%$ lower than that of diesel, respectively. The amount of fuel injected increases the BP fuel-air mixture. The SAME and SAME blends provide oxygen to boost the combustion process and reduce fumigation densities compared to diesel.

\subsubsection{UnBurnt HydroCarbon (UBHC) emission}

In Figure 11, various mixtures display hydrocarbon emissions with diverse brake power. Due to the rich mix, higher $\mathrm{BP}$ was observed. The UBHC emissions are found to increase with BP. The UBHC emissions for fuels measured at all loads compared with diesel increase dramatically with different loads and mixtures. SAME and SAME blends UBHC emissions are respectively $17 \%$ and $15 \%$ higher than diesel.

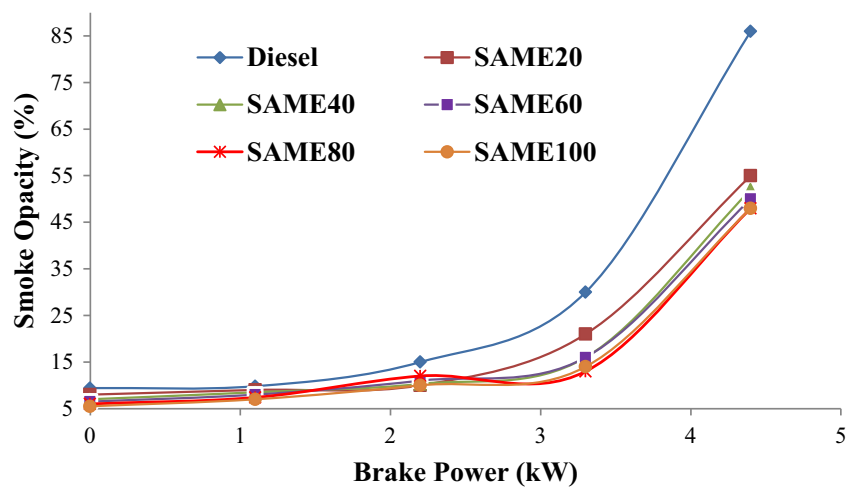

Fig. 10. Variation of smoke density.

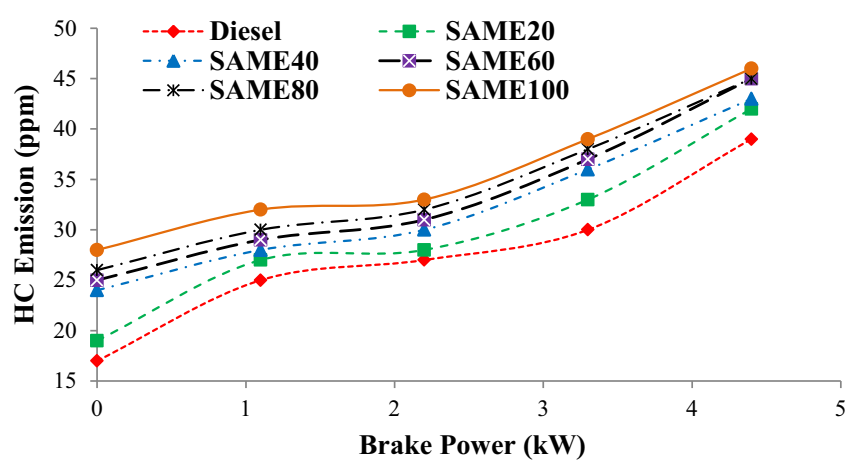

Fig. 11. Variation of UBHC emission.

The rich blend in some places of the combustion chamber increases UBHC emission significantly with higher BP. Since the highest frequency temperature is the highest, the availability of rich combustion mixture due to increased fuel injector quantities into the combustion chamber contributes to UBHC emissions.

\subsubsection{CO emission}

Figure 12 illustrates the $\mathrm{CO}$ emission for various mixtures of different BP. As the ratio of air fuels decreases with a higher $\mathrm{BP}, \mathrm{CO}$ emissions are increased. The $\mathrm{CO}$ emissions are almost the same in all fuels up to $50 \%$ of maximum $\mathrm{BP}$ and are further lower in the SAME and SAME blends combination than the $\mathrm{CO}$ emissions in diesel. Greater unsaturated SAME/SAME blends fatty acids will increase the oxidation process and reduce $\mathrm{CO}$ emissions. SAME and SAME blends enhance combustion, oxygen stimulates combustion and decreases $\mathrm{CO}$ emissions compared to diesel.

\subsection{Performance analysis}

\subsubsection{Brake thermal efficiency}

Figure 13 demonstrates the brake thermal efficiency variance for different test fuels. For the SAME and SAME 


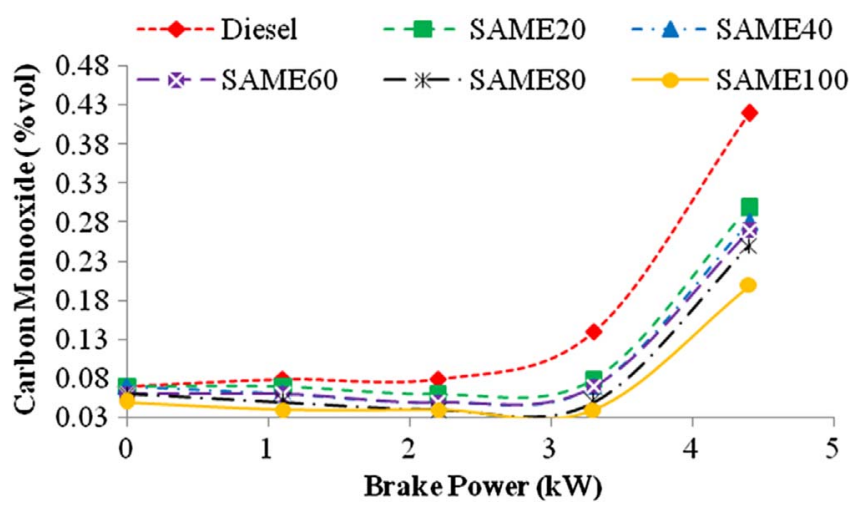

Fig. 12. Variation of $\mathrm{CO}$ emission.

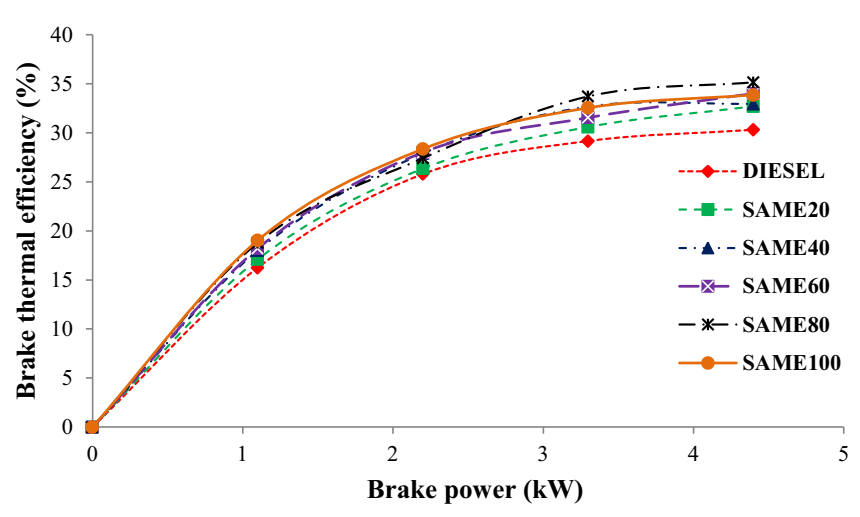

Fig. 13. Variation of brake thermal efficiency.

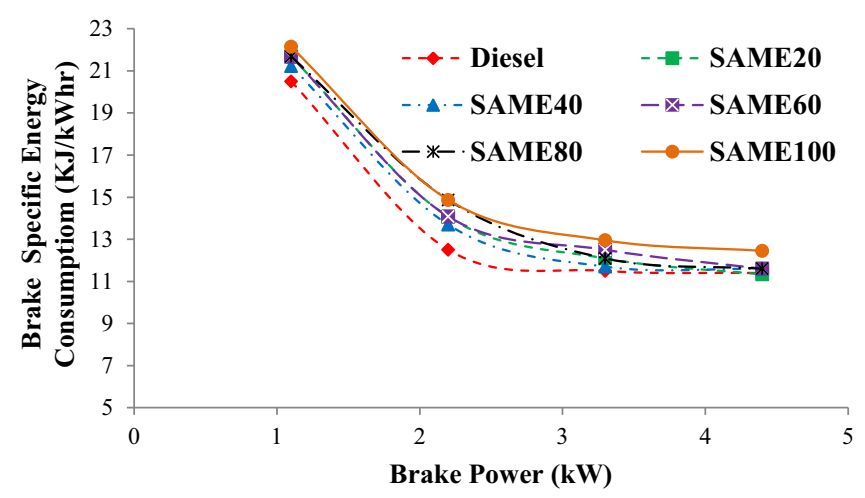

Fig. 14. Variation of brake specific energy consumption.

blends compared to diesel for all of BP, thermal efficiency is slightly higher. For the SAME and SAME blends compared to diesel, the overall improvement in efficiency is $3.38 \%$.

The SAME and SAME blends have shorter ignition delay as the engine is run under advanced injection, combustion starts before TDC. In the vicinity of TDC, maximum heat is released, the highest efficiency is noted. The thermal efficiency is increased near the TDC for SAME and the SAME blends, which induce and deviate from the ideal cycle (Yesilyurt et al., 2020).

\subsubsection{Brake specific energy consumption}

Figure 14 explains the basic brake specific energy consumption with BP. Specific energy consumption for the SAME reduced up to a part load for SAME blend and diesel and then increases. In all biodiesel blends, the basic energy requirements for diesel are shown to be lower and greater. Since SAME and its mixture have less power than diesel. To produce the SAME power as the heat benefit of the blend, the engine uses more combined fuel than diesel. Due to the decrease in the heating value of a blend the specific energy consumption is rising slowly along with blend percentage (Isik et al., 2020).

\section{Conclusion}

From the combustion, emission and performance behaviour of diesel, SAME and SAME blends, it is inferred that

- The SAME and SAME blends are equivalent to diesel combustion characteristics.

- In contrast with diesel, SAME and SAME blends indicate decreased CO emission, smoke opacity and slightly higher UBHC emissions.

- The NOx emission of diesel is lower than the SAME and SAME blends.

- Thermal efficiencies of the SAME and SAME blends are higher compared to diesel and diesel displays with low thermal efficiency.

- SAME demonstrates a drop in smoke opacity above the SAME blends and a marginally high emission of NOx in a diesel engine.

- Smoke opacity and brake thermal efficiency are found to be the lowest as compared to diesel.

- As fuel for the diesel engine, it is ideal to use the SAME and SAME blends. SAME and SAME blends combinations are also found to be capable of substituting diesel.

\section{References}

Antolin G., Tinaut F.V., Briceno Y., Castano V., Perez C., Ramirez A.I. (2002) Optimization of biodiesel production by sunflower oil transesterification, Bioresour. Technol. 83, 111114. https://doi.org/10.1016/S0960-8524(01)00200-0.

Broatch A., Tormos B., Olmeda P., Novella R. (2014) Impact of biodiesel fuel on cold starting of automotive direct injection diesel engines, Energy 73, 653-660.

Capecchi L., Nissen L., Modesto M., Girolamo G.D., Cavani L., Barbanti L. (2017) Crop Factors Influencing Ethanol Production from Sorghum Juice and Bagasse, Energies 10, 940. https://doi.org/10.3390/en10070940.

Carlos C.D., Carpintero O., Frechoso F., Mediavilla M., de Miguel L.J. (2014) A top-down approach to assess physical and ecological limits of biofuels, Energy 64, 506-512.

Demirbas A. (2007) Recent developments in biodiesel fuels, Int. J. Green Energy 4, 15-26. https://doi.org/10.1080/ 15435070601015395 . 
Dorado M.P., Ballesteros E., Arnal J.M., Gomez J., Lopez Gimenez F.J. (2003) Testing waste olive oil methyl ester as a fuel in a diesel engine, Energy Fuels. 17, 1560-1565. https://doi.org/10.1021/ef0202485.

Dwivedi G., Sharma M.P. (2014) Impact of cold flow properties of biodiesel on engine performance, Renewable Sustainable Energy Rev. 31, 650-656.

Hoekman S.K., Broch A., Robbins C., Ceniceros E., Natarajan M. (2012) Review of biodiesel composition, properties, and specifications, Renewable Sustainable Energy Rev. 16, 143-169.

Isık M.Z., Topkaya H., Iscan B., Aydın H. (2020) Combustion, performance, and emissions of safflower biodiesel with dimethyl ether addition in a power generator diesel engine, Energy Sources Part A 1, 1-16. https://doi.org/10.1080/ 15567036.2020.1756993.

Karabas H. (2014) Application of the taguchi method for the optimization of effective parameters on the safflower seed oil methyl ester production, Int. J. Green Energy 11, 1002-1012. https://doi.org/10.1080/15435075.2013.829475.

Kaulani S.A., Latiff Z.A., Perang M.R.M., Said M.F.M., Hasn M. F. (2019) Performance and emission of compression ignition (CI) engine using ethanol - diesel blending as a fuel, AIP Conf. Proc. 2059, 020019. https://doi.org/10.1063/1.5085962.

Kinoshita E., Hamasaki K., Jaqin C., Takasaki K. (2004) Combustion characteristics for diesel engines with emulsified biodiesel without adding emulsifier, SAE Technical Paper 2004-01-1860. https://doi.org/10.4271/2004-01-1860.

Kowalewicz A., Wojtyniak M. (2005) Alternative fuels and their application to combustion engines, Proc. Inst. Mech. Eng. D J. Auto. Eng. 219, 103-125. https://doi.org/10.1243/ 095440705 X6399.

Lesnik L., Kegl B., Torres-Jimenez E., Cruz-Peragon F. (2020) Why we should invest further in the development of internal combustion engines for road applications, Oil Gas Sci. Technol. - Rev. IFP Energies nouvelles 75, 56.

Murugan S., Ramaswamy M.C., Nagarajan G. (2008) Performance, emission and combustion studies of a DI diesel engine using distilled tyre pyrolysis oil-diesel blends, Fuel Process. Technol. 89, 152-159.

Ozsezen A.N., Canakci M. (2011) Determination of performance and combustion characteristics of a diesel engine fueled with canola and waste palm oil methyl esters, Energy Convers. Manage. 52, 108-116. https://doi.org/10.1016/j.enconman. 2010.06.049.

Schlick M.L., Hanna M.A., Schinstock J.L. (1988) Soybean and sunflower oil performance in a diesel engine, Trans. ASAE 31, 1345-1349. https://doi.org/10.13031/2013.30868.

Sharp C., Ryan T., Knothe G. (2005) Heavy-duty diesel engine emissions tests using special biodiesel fuels, SAE Trans. 114, 1204-1212. http://www.jstor.org/stable/44721038.

Sirman M., Owens E., Whitney K. (2000) Emissions comparison of alternative fuels in an advanced automotive diesel engine, SAE Trans. 109, 2166-2176. http://www.jstor.org/stable/ 44746010 .

Soares S., Rocha F.R. (2018) Fast Spectrophotometric determination of iodine value in biodiesel and vegetable oils, J. Braz. Chem. Soc. 29, 8, 1701-1706. https://doi.org/10.21577/01035053.20180044 .

Tutak W., Jamrozik A., Pyrc M., Sobiepański M. (2016) Investigation on combustion process and emissions characteristic in direct injection diesel engine powered by wet ethanol using blend mode, Fuel Process. Technol. 149, 86-95. https://doi.org10.1016/j.fuproc.2016.04.009.

Vignesh P., Kumar A.R.P., Ganesh N.S., Jayaseelan V., Sudhakar K. (2021) Biodiesel and green diesel generation: An overview, Oil Gas Sci. Technol. - Rev. IFP Energies nouvelles $\mathbf{7 6}, 6$.

Yesilyurt M.K., Yilbasi Z., Aydin M. (2020) The performance, emissions, and combustion characteristics of an unmodified diesel engine running on the ternary blends of pentanol/ safflower oil biodiesel/diesel fuel, J. Therm. Anal. Calorim. 140, 2903-2942. https://doi.org/10.1007/s10973-020-09376-6. 